\title{
Product Differentiation at the Movies: Hollywood, 1946 to 1965
}

JOHN SEDGWICK

In the post-Second World War period the floor fell out of the market for films in the United States. However, while the average revenue of films fell, the "hit" end of the market sustained itself. The growing inequality in the distribution of revenues meant that the risks associated with high-budget productions could no longer be balanced against the steady earnings of medium-budget films. During the 1950s the "majors" all became distributor-financiers as they reduced their exposure to the risks associated with film production. In doing this they retained their dominant position in the industry.

$\mathrm{P}$ opular film was a most important twentieth-century commodity. It is worthy of study by the economic historian, not because it employed many people, which it did not, or because it contributed greatly to national income, which it did not, but because it attracted extremely large numbers of consumers to spend time voluntarily, in preference to other activities, experiencing some measure of well-being derived from sequences of moving images and their associated aesthetics. ${ }^{1}$ Audiences across the globe now consume films through a variety of media, but in the years immediately following the end of the Second World War consumption was confined to movie theaters alone. At that time U.S. audiences, when counted by ticket admissions, were at an all time high with an annual count of four and a half billion (33 visits per capita), dwarfing those attracted by other paid-for leisure activities. ${ }^{2}$ After 1946 admissions fell continuously to a low point of 0.82 billion in 1972 , followed by a gentle recovery. During this period the mode of film consumption diversified from the movie theater alone to home viewing on television sets through the TV networks. Not long thereafter,

The Journal of Economic History, Vol. 62, No. 3 (Sept. 2002). (C) The Economic History Association. All rights reserved. ISSN 0022-0507.

John Sedgwick is Principal Lecturer in Economics, Business School, University of North London, Holloway, London N7 8DB, United Kingdom. E-mail: j.sedgwick@unl.ac.uk.

This article was made possible by a grant from the Leverhulme Trust, for whom I was a Research Fellow between 2000 and 2001. I owe a great debt of thanks to Peter Armitage and Bernard Hrusa Marlow for helping me shape the article. I also want to thank Sam Cameron, John Curran, Mark Glancy, Manfred Holler, Ian Jarvie, James Obelkevich, Mike Pokorny, and Guglielmo Volpe for their critical contributions at various stages of the project. Comments from participants of seminars at Humbolt University, Berlin, and the Institute of Historical Research, London, and Southampton University, in the United Kingdom, also helped me form the final draft, as did the reviews of two anonymous referees.

${ }^{1}$ In 1946 box-office revenues constituted 1.1 percent of total personal consumption expenditure in the United States, falling to 0.2 percent by 1965. U.S. Department of Commerce, Bureau of the Census, Historical Statistics. It is interesting to note that not one of the 17 chapters of volume 3 of Engerman and Gallman's recent Economic History of the United States takes a consumption perspective.

${ }^{2}$ U.S. Department of Commerce, Bureau of the Census, Historical Statistics, Series H, 862-77. 
video, cable, and more recently satellite dishes brought movies to the little screen. ${ }^{3}$ Computer screens now constitute a third medium. Remarkably, during these changes, as before them, Hollywood has continued to dominate the global market for film. ${ }^{4}$

The American market for film entertainment was, and remains, by far the most important source of theatrical revenue for film producers, contributing approximately half of total world-wide sales in 1965. Unlike today, when approximately 70 per cent of film revenue is derived from nontheatrical sources, rental income from the box-office was almost the sole source of revenue for production companies during the period under investigation. ${ }^{5}$ Indeed, rental agreements with the TV networks did not start to return a significant portion of the costs of film production until the widespread diffusion of color television during the late 1960 s and early 1970 s. $^{6}$ Before this Hollywood's earnings from television came not so much from its library of vintage films locked away in studio vaults as from its production of contemporary made-for-TV movies and celebrity shows. ${ }^{7}$

However, this strategic response to declining audience numbers was not unproblematic for the major studios. Extending their product portfolio to made-for-television programs and films did not lessen the problem of how to compete effectively in the diminishing market for feature films and how, if possible, to arrest this decline. After all, making films, and distributing and screening them had constituted the core business of Hollywood since the late 1910 s. ${ }^{8}$ In 1946 the principal studios dominated production and distribution, and five of them, Loew's-MGM, Paramount, RKO, Twentieth Century Fox, and Warners, controlled a significant share of the first-run exhibition market, from which they were compelled to disengage themselves as a result the Supreme Court's Paramount Divorcement Decree of $1948 .^{9}$ By 1965 most of the films released by the same studios were made by production companies whose existence was short-lived, if not confined solely to the production of a single film output, and shown in divested theaters.

The change in the organizational configuration of Hollywood is commonly explained as a consequence of the major studios no longer having a guaranteed retail outlet for their product. ${ }^{10}$ This article proposes a different explanation based upon the changing pattern of demand: namely, that during

\footnotetext{
${ }^{3}$ See Vogel, Entertainment, ch. 2.

${ }^{4}$ See Hoskins, McFadyen, and Finn, Global Television; Jarvie, Hollywood's Overseas Campaign; Storper, "Flexible Specialization"; and Thompson, Exporting Entertainment.

${ }^{5}$ See Vogel, Entertainment, pp. 58-63; and Film Daily Yearbook, 1966, p. 100.

${ }^{6}$ Izod, Hollywood and the Box Office, p. 166-170.

${ }^{7}$ Gomery, "Toward a New Media Economics," pp. 407-08.

${ }^{8}$ Balio, Grand Design; Crafton, Talkies; and Thompson, Exporting Entertainment.

${ }^{9}$ Prior to divestiture the five "majors" owned 70 per cent of first-run movie theaters. See Conant, Antitrust, p. 50. Also see De Vany and Eckert "Motion Picture Antitrust"

${ }^{10}$ Izod, Hollywood and the Box-Office, pp. 124-25; and De Vany and Eckert, "Motion Picture Antitrust," pp. 53-54.
} 
the period 1946-1965 not only did U.S. box-office revenues fall dramatically, but they became increasingly unequally distributed, so that whereas the rental income of the annual top-ten films held up over the period, films ranked in lower classifications performed progressively poorly. These changes made untenable the portfolio approach to risk that had characterized studio production during the preceding two decades: middle- and low-budget films could no longer be relied upon to attenuate the risks associated with big-budget production. ${ }^{11}$ The outcome of this was that studio production became increasingly focused on the production of "hit" films. To make their films more attractive to audiences, studios spent increasing amounts in order to enhance production values, including the introduction of an array of visual and audio innovations. ${ }^{12}$ Audiences for their part were becoming more occasional and selective. The evidence is that they responded to the perceived quality of certain "event" films in relation to all other films. In the words of the movie mogul Darryl F. Zanuck:

There is no such thing as a 'safe' field. Theatregoers are more selective than ever before.... This does not mean that every picture we make must be a freak attraction completely off the beaten path but it does mean that it must have at least an idea that will lift it out of the commonplace. ${ }^{13}$

Although it may be true that demographic and other social changes lowered the average age of the audience over the period, leading to the rise in the number of films directed towards juvenile audiences, it was rare for one of these niche films to occupy an annual top-ten berth. ${ }^{14}$ Market fragmentation can account for the emergence of the host of small-time opportunistic independent producers but it does not explain the central position in the movie business retained by the major Hollywood studios.

\section{THE CONTEXT}

In the immediate postwar period the United States experienced rapid social change occasioned by the growth in real disposable incomes, the build-up of wartime savings, and the explosion in the birth rate. As David Halberstam has written, “. . . this was one of the great sellers' markets of all time. There was a desperate hunger for products after the long drought of fifteen years caused by the Depression and then World War Two." 15 The same author identifies the key symbolic products of the late 1940s and 1950s

\footnotetext{
${ }^{11}$ Sedgwick and Pokorny, "Risk Environment."

${ }^{12}$ Belton, Widescreen Cinema.

${ }^{13}$ Letter to Henry King, 14 June 1950, quoted in Custen, Twentieth Century's Fox, p. 319.

${ }^{14}$ One that succeeded was the Beatles' film A Hard Day's Night which in 1964 was ranked ninth.

${ }^{15}$ Halberstam, Fifties, p. 118.
} 
as cars, suburban (Levitt) homes - full of consumer durables, including televisions, bought at suburban (Korvettes) discount stores, fast food (McDonald's), and advertising. ${ }^{16}$ To these should be added a whole range of equipment to go with expanding outdoor recreation activities including tourism, golf, gardening, participatory sports, and fishing. ${ }^{17}$

Films were not on this list. Indeed audiences had stopped going to the movies in large numbers. Referencing social-survey evidence of 1948, Conant identified the pressure on consumers' time as the most important factor in the decline of ticket sales. ${ }^{18}$ Douglas Gomery writes:

When middle-class Americans moved to the suburbs in record numbers after the Second World War, they also abandoned propinquity to the matrix of downtown and neighbourhood movie theatres. In addition, these young adults, previously the most loyal fans, concentrated on raising families. ${ }^{19}$

Table 1 reports the period as one of intensive urbanization. The proportion of Americans living in urban areas, defined as cities with a population larger than 100,000, expanded from 46 percent in 1950 to 58 percent by 1970 . More startling, however, is the growth in the number of Americans living in fringe areas of cities as opposed to city centers. Whereas the latter grew by 32 percent over the period, the suburban population grew by 161 percent, a compound annual growth rate of over 5 percent per year. Of course the record number of housing starts made this population movement to the suburbs possible, with the housing stock increasing by a quarter during both the 1940s and 1950s. ${ }^{20}$ Alongside these changes was the increase in home ownership, rising dramatically from 44 percent in 1940 to 55 percent in 1950 and to 62 percent in $1960 .^{21}$ The change in lifestyle that went with suburbanization is of course a subject for numerous films during the period.

The baby boom is captured in columns 4-7 of Table 1 . The number of under-fives increased by 57 percent during the 14 years between 1946 and 1960, at a rate of 3.5 percent per annum. Likewise the 5-14 age range also mushroomed - a 64 percent growth between these same years at an annual rate of 3.9 percent - while the next two age categories remained static. For men and women in their 20s and early 30 s there were many more pre-school and school-age children to be cared for.

Hence, although Americans had on average more leisure time at their disposal in the postwar period with the onset of institutional vacations and the decline in Saturday working, they found additional claims on their growing

\footnotetext{
${ }^{16}$ See also Rome, Bulldozer.

${ }^{17}$ Clawson and Knetch, Outdoor Recreation; and Oakley, God's Country.

${ }^{18}$ Conant, Antitrust in the Motion Picture Industry, p. 12.

${ }^{19}$ See also Gomery, Shared Pleasures, p. 83.

${ }^{20}$ For an overview of the dramatic changes to the housing sector see Rome, Bulldozer.

${ }^{21}$ U.S. Census Bureau: Historical Census of Housing.
} 
TABLE 1

SELECTED U.S. POPULATION STATISTICS, 1946-1970

\begin{tabular}{|c|c|c|c|c|c|c|c|}
\hline Year & $\begin{array}{l}\text { U.S. } \\
\text { Population } \\
(000 \mathrm{~s}) \\
(1)\end{array}$ & $\begin{array}{c}\text { Urbanized } \\
\text { Areas } \\
\text { Central } \\
\text { Cities } \\
(000 \mathrm{~s}) \\
(2)\end{array}$ & $\begin{array}{c}\text { Urbanized } \\
\text { Areas } \\
\text { Suburbs } \\
(000 \mathrm{~s}) \\
(3)\end{array}$ & $\begin{array}{l}\text { Persons } \\
\text { Aged } \\
\text { Under } 5 \\
(000 \mathrm{~s}) \\
(4)\end{array}$ & $\begin{array}{c}\text { Persons } \\
\text { Aged } \\
5-14 \\
(000 s) \\
(5)\end{array}$ & $\begin{array}{c}\text { Persons } \\
\text { Aged } \\
15-24 \\
(000 s) \\
(6)\end{array}$ & $\begin{array}{c}\text { Persons } \\
\text { Aged } \\
25-34 \\
(000 \mathrm{~s}) \\
(7)\end{array}$ \\
\hline 1946 & - & - & - & 12,974 & 21,844 & 23,382 & 22,954 \\
\hline 1950 & 151,684 & 48,337 & 20,872 & 16,331 & 24,477 & 22,260 & 23,932 \\
\hline 1960 & 180,671 & 57,975 & 37,873 & 20,341 & 35,735 & 24,576 & 22,919 \\
\hline 1970 & 204,879 & 63,922 & 54,525 & 17,156 & 40,733 & 36,496 & 25,293 \\
\hline
\end{tabular}

Source: United States Department of Commerce, Bureau of the Census, Historical Statistics of the United States, chapter A, series 29-42, 82-90, and 288-319.

recreational budget through alternative recreational activities as well as family and house-owning responsibilities. ${ }^{22}$ Between 1946 and 1950 cinema audiences declined by a third, even though admission prices were falling in real terms. ${ }^{23}$ From 1950 television became an additional attraction for Americans and the chief cause in the further decline of attendance numbers. The astonishing speed at which television services were diffused across the American population is captured in column 5 of Table 2. In 1950 fewer than 9 percent of American households possessed a television, yet five years later the proportion had risen to 64 percent. Stanford Research Institute issued a report in which researchers showed that the diffusion of television accounted for more than 70 percent of the drop in motion-picture revenues in 1950 and 1951 , falling to 60 percent in 1952, 58 percent in 1953, and 55.8 percent in $1954 .^{24}$ Interestingly, the growth in television viewing brought with it a demand for vintage films. ${ }^{25}$

In contrast to those exogenous factors responsible for the decline in audience numbers highlighted above, Robert Sklar has focused attention upon the contemporary reception of the product itself. ${ }^{26}$ Drawing upon scholarly work of the time he reports a series of conflicting arguments. Whereas all contemporary commentators accepted Handel's findings — that younger people attended the cinema more regularly than did older people, and that moviegoers tended to have more education and were of a higher socioeconomic status than the average citizen but were equally spread between

\footnotetext{
${ }^{22}$ Clawson and Knetsch, Outdoor Recreation.

${ }^{23}$ Conant, Antitrust: table 1, reports that average admission prices remained largely unchanged between 1946 and 1952 - hence falling in real terms. His own estimate of attendances is lower than that reported in official publications.

${ }^{24}$ Conant, Antitrust, p. 14

${ }^{25}$ Conant, Antitrust, pp. 13-14

${ }^{26}$ Sklar, Movie-Made America and "Lost Audience."
} 
TABLE 2

SELECTED PERSONAL CONSUMPTION STATISTICS, 1946-1970

(all money values in millions of dollars, 1958 prices)

\begin{tabular}{|c|c|c|c|c|c|}
\hline Year & $\begin{array}{l}\text { Total Personal } \\
\text { Consumption } \\
\text { Expenditure } \\
\text { (1) }\end{array}$ & $\begin{array}{c}\text { Recreational } \\
\text { Expenditure } \\
\text { (2) }\end{array}$ & $\begin{array}{c}\text { Total U.S. } \\
\text { Box Office } \\
\text { (3) }\end{array}$ & $\begin{array}{l}\text { Average Weekly } \\
\text { Movie } \\
\text { Attendance } \\
\text { (millions) } \\
\text { (4) }\end{array}$ & $\begin{array}{l}\text { Households } \\
\text { with TV sets } \\
(000 \mathrm{~s}) \\
(5)\end{array}$ \\
\hline 1946 & 203,404 & 12,112 & 2,400 & 90 & 8 \\
\hline 1950 & 230,409 & 13,446 & 1,660 & 60 & 3,875 \\
\hline 1955 & 274,117 & 15,170 & 1,429 & 46 & 30,700 \\
\hline 1960 & 316,075 & 17,779 & 924 & 40 & 45,750 \\
\hline 1965 & 397,830 & 24,171 & 852 & 44 & 52,700 \\
\hline
\end{tabular}

Source: United States Department of Commerce, Bureau of the Census, Historical Statistics, chapter G, series 416 and 452; chapter H, series 874 and 884; chapter R, series 93-105. The price deflator used throughout the study is that given for total consumer expenditure, chapter E, series 2 .

the genders - they were interpreted in a variety of ways. ${ }^{27}$ Paul F. Lazarsfeld maintained that youth had become the chief arbiters of film success: they were its opinion leaders. ${ }^{28}$ David and Evelyn Riesman concurred, arguing that the incipient orientation of film making towards the taste of youth resulted in films that proved to be too fast and difficult to keep up with for older filmgoers. ${ }^{29}$ Gilbert Seldes, however, believed that pandering to youth had resulted in a lowering of cinematic standards and that it was this that had turned audiences away. ${ }^{30}$ Eliot Friedson found that the cinema became a place where young people could be in a social setting of their own making, apart from the authority structures that normally governed their lives. ${ }^{31}$

With the decline in attendance the proportion of young people in the audience increased, so that by 1957 three-quarters of audiences were under 30 and half under 20 years of age. ${ }^{32}$ A criticism leveled at Hollywood was that the major studios failed to respond vigorously to this market information. Indeed Sklar has argued that the logic of the situation demanded that Hollywood should have tried harder at attracting less-educated and lowerincome groups. ${ }^{33}$ However, such strategies were anathema to the studio moguls who conceived their audience to be essentially homogeneous, characterized by a range of "middle-class" tastes that were known to, and intuitively understood by, them. ${ }^{34}$ This opinion is no doubt overstated. One has

\footnotetext{
${ }^{27}$ Handel, Hollywood.

${ }^{28}$ Lazarsfeld, "Audience Research."

${ }^{29}$ Riesman and Riesman, "Movies."

${ }^{30}$ Seldes, G. Great Audience.

${ }^{31}$ Friedson, E. "Consumption."

${ }^{32}$ MPPA, The Public Appraises the Movies, p. 4, quoted in Belton, Widescreen Cinema, p. 81.

${ }^{33}$ Sklar, Movie-Made America, p. 271.

${ }^{34}$ Sklar, Movie-Made America, pp. 270-71. Men such as Louis B. Mayer (MGM), Harry Cohn (Columbia), David O. Selznick (Selznick International), Darryl F. Zanuck (20th Century Fox), Barney
} 
only to examine the great mix of film-types categorized by genre from, say, the mid-1920s to realize that "old" Hollywood also produced films for niche markets. ${ }^{35}$ Nevertheless, it would also be true to say that middle- and bigbudget films were designed to achieve maximum penetration in the market place, and this was achievable only if audiences had a common conception of film quality. To assess the studios' strategic response to the declining market it seems sensible to begin with the box-office.

\section{THE DATA}

Beginning in 1946 the weekly trade journal Variety published in either its first or second issue in January of each year an annual list of the most popular films released onto the American market, together with the rental incomes they generated for their distributors. ${ }^{36}$ The data set of 1,820 films, which includes between 61 and 130 top-ranking films for each year of the study, provides a unique empirical source from which to study Hollywood during this time of declining theatrical audience. The numbers of films reported each year-labeled "Top Grossers" by Variety - are found in column 1 of Table 3 and were selected on the grounds that they generated a threshold number of dollars at the U.S. and Canadian box-office, net of the exhibitor's take. In 1946 this threshold was $\$ 2.25$ million. ${ }^{37}$ The threshold was lowered to $\$ 2$ million for the 1947 season, $\$ 1.5$ million for 1948 and $1949, \$ 1.25$ million for 1950 , and $\$ 1$ million for the remaining years of the study. Initially, the reduction in the threshold more than counterbalanced the falling demand for films, because it admitted more films on to the "Top Grossing" list during the period up to 1953. Thereafter, the number of films listed fell.

On the surface the Variety returns might not appear to be a good basis for developing a thesis. They certainly were not produced from within an academy, or as the outcome of scientific method. The bases of the estimates were not recorded and hence are not transparent. ${ }^{38}$ Nevertheless, however imperfect they are, they are all that historians have to work with. ${ }^{39}$ A two-fold case can be made to justify the use of the Variety lists. First, the trade treated the data with respect. They told a story about the relative and absolute popularity of films that accorded with the experience of those whose livelihoods

\footnotetext{
Balaban (Paramount), Sam Goldwyn (Goldwyn), and Jack Warner (Warner Bros.) had all been studio executives-chiefs from at least the beginning of the 1930s.

${ }^{35}$ Maltby, "Sticks."

${ }^{36}$ To be shared subsequently with the producer according to contract.

${ }^{37}$ The rentals do not contain overseas figures, estimated in 1961 to be approximately equal to domestic rentals. Variety, 10 January 1962, p. 13.

${ }^{38}$ Besas, Inside Variety, pp. 281-83.

${ }^{39}$ See Crafton, D. Talkies, p. 521.
} 
TABLE 3

BOX-OFFICE REVENUES OF “TOP GROSSING” FILMS, 1946-1956

(all money values in millions of dollars, 1958 prices)

\begin{tabular}{|c|c|c|c|c|c|}
\hline Year & $\begin{array}{l}\text { Number of } \\
\text { Films Listed } \\
\text { in Variety } \\
\text { as "Top } \\
\text { Grossers" } \\
\text { (1) }\end{array}$ & $\begin{array}{c}\text { Number of } \\
\text { "Top Grossers" } \\
\text { Distributed by the } \\
\text { Major Hollywood } \\
\text { Studios } \\
\text { (2) }\end{array}$ & $\begin{array}{l}\text { Net Rental } \\
\text { Income of } \\
\text { Films Listed } \\
\text { in Variety } \\
\text { (3) }\end{array}$ & $\begin{array}{l}\text { Mean Rental } \\
\text { Income of } \\
\text { Variety- } \\
\text { Listed Films } \\
\text { (4) }\end{array}$ & $\begin{array}{c}\text { Total U.S. } \\
\text { Box Office } \\
\quad(5)\end{array}$ \\
\hline 1946 & 61 & 61 & 303.55 & 4.98 & $2,400.00$ \\
\hline 1947 & 75 & 75 & 329.27 & 4.39 & $2,046.21$ \\
\hline 1948 & 92 & 90 & 278.61 & 3.03 & $1,829.89$ \\
\hline 1949 & 89 & 86 & 246.14 & 2.77 & $1,776.01$ \\
\hline 1950 & 95 & 92 & 263.67 & 2.78 & $1,659.83$ \\
\hline 1951 & 130 & 130 & 277.40 & 2.13 & $1,478.56$ \\
\hline 1952 & 118 & 115 & 294.10 & 2.49 & $1,376.80$ \\
\hline 1953 & 131 & 129 & 329.67 & 2.52 & $1,294.44$ \\
\hline 1954 & 112 & 109 & 301.89 & 2.70 & $1,327.57$ \\
\hline 1955 & 107 & 103 & 341.97 & 3.20 & $1,428.88$ \\
\hline 1956 & 106 & 101 & 272.42 & 2.57 & $1,470.46$ \\
\hline 1957 & 95 & 92 & 293.27 & 3.09 & $1,152.51$ \\
\hline 1958 & 76 & 70 & 249.17 & 3.28 & 992.00 \\
\hline 1959 & 82 & 79 & 224.89 & 2.74 & 945.71 \\
\hline 1960 & 74 & 65 & 244.55 & 3.30 & 924.20 \\
\hline 1961 & 75 & 71 & 235.90 & 3.15 & 886.43 \\
\hline 1962 & 72 & 67 & 238.90 & 3.32 & 860.82 \\
\hline 1963 & 77 & 68 & 301.31 & 3.91 & 852.03 \\
\hline 1964 & 70 & 67 & 229.54 & 3.28 & 850.09 \\
\hline 1965 & 83 & 79 & 355.07 & 4.28 & 852.02 \\
\hline
\end{tabular}

a Taken here to include Columbia, Disney, Loew's-MGM, Paramount, RKO, Twentieth Century Fox, United Artists, Universal, and Warner Bros.

Note: The film rental data reported in Variety for any particular year included estimates for those films which were released during the year and were still on release. Occasionally, these films appeared as "Top Grossers" during the following year with an updated figure. These films and their revenues have been attributed to the year of release. For the greater part of the period re-releases were relatively uncommon with the life cycle of films on theatrical release being completed within 15 months. See Greenwald, The Motion Picture Industry. Only five re-releases made the Variety charts: Bridge on the River Kwai, reissued in 1964: Cinderella reissued in 1965; Gone With the Wind reissued in 1961; Hollywood Canteen reissued in 1954; and So Dear To My Heart reissued in 1964.

Sources: Variety; United States Department of Commerce, Bureau of the Census, Historical Statistics.

were bound up in the film business. This is most important, because without such verity it seems highly unlikely that Variety would have continued to serve as the principal trade publication. Second, the reported rental incomes correlate, statistically, very strongly with the returns of three "major" studios found in their business ledgers, which were uncovered during the 1990s and published in part in microfiche form by the Historical Journal of Film, Radio and Television. ${ }^{40}$

\footnotetext{
${ }^{40}$ See Glancy, "MGM Film Grosses" and "Warner Bros. Film Grosses"; and Jewell, "RKO Film Grosses." Glancy and Jewell have kindly made the full manuscripts available to the author.
} 
From Table 3 it is clear that although the total box-office revenues of theatrical releases declined to about a third of their starting value over the period, the rental income accruing to the distributors of those films found in the Variety lists experienced a much smaller decline. Some technical problems must be dealt with in analyzing these two series. The Variety data include Canadian revenues, whereas the U.S. government statistics do not. This complicates the analysis but not damagingly, because of the relatively small size of the Canadian market. ${ }^{41}$ A more serious difficulty is the point in the supply chain at which the data have been collected; in the case of Variety the source is the rental incomes of the distribution companies, whereas the U.S. Government data represent the box-office revenue captured by exhibitors. Joel Finler has suggested that the rental income constituted approximately half of the total box-office gross, with the other half going to the exhibitor. ${ }^{42}$ The Film Daily Yearbook suggests that this proportion is a little above a third. ${ }^{43}$ As the figures stand in Table 3, it is apparent that the market share of Variety-listed films increased dramatically over the period. If the conservative assumption is made that rental incomes were half the annual box-office revenue, the top films increased their share from 26 percent in 1946 to 84 percent by $1965 .^{44}$

The period under investigation was notable for the increasing inequality of rental incomes. Table 4 shows of the rental income generated by the 60 top films for each year and the proportion of it attributed to films ranked in sets of ten. ${ }^{45}$ A first observation is the growing significance of the top ranking films as money earners. Column 4 shows that the top 10 films significantly increased their share of the rental income generated by the top 60 films. This rose from approximately a quarter during the immediate postwar years to above 30 percent during the much of the 1950s, climbing to over 40 percent for most of the years from 1957 onwards and peaking at 51 percent in 1965. Further, the actual revenues that accrued to these films also rose in real terms, trending upwards from postwar-low levels of less than $\$ 50$ million in 1949 and 1951, to aggregate rental incomes of above \$100 million in 1957, 1958, 1960, 1963 and 1965. The peaks were generated by the extraordinary success of a small number of films. These films were: in the boxoffice year 1957, The Ten Commandments (\$34.2 million) and Around the World in 80 Days (\$22 million); in 1958, South Pacific (\$17.5 million)

\footnotetext{
${ }^{41}$ Figures published in Vogel, Entertainment, table 2.4, indicate that rental incomes generated in Canada were less than 10 percent of those in the United States.

${ }^{42}$ Finler, J. Hollywood Story, p. 276.

${ }^{43}$ The Film Daily figures (unattributed) are similar to those found in Vogel, Entertainment, table 2.4.

${ }^{44}$ These shares are obtained by halving column 5 of Table 3 and expressing rental income as a percentage. They are "conservative" because if the lower proportion is used, the market share of the "Top Grossing" films would be even greater.

${ }^{45}$ The top 60 films have been used in order to standardize rental income observations across the period. These films took between 69 and 99 percent of the rental incomes reported in Table 2.
} 
TABLE 4

PROPORTIONAL DISTRIBUTION OF RENTAL INCOME OF ANNUAL TOP 60 FILMS, 1946-1965

(column 1 in millions of dollars, 1958 prices)

\begin{tabular}{|c|c|c|c|c|c|c|c|c|c|}
\hline \multirow[b]{2}{*}{ Year } & \multirow{2}{*}{$\begin{array}{c}\text { Top } 60 \\
\text { Rental } \\
\text { Income } \\
(1)\end{array}$} & \multirow{2}{*}{$\begin{array}{c}\text { Coefficien } \\
\text { t of } \\
\text { Variation } \\
(2)\end{array}$} & \multirow{2}{*}{$\begin{array}{c}\text { Gini } \\
\text { Coefficien } \\
\mathrm{t} \\
(3)\end{array}$} & \multicolumn{6}{|c|}{ Films Ranked } \\
\hline & & & & $\begin{array}{c}1-10 \\
\text { (4) }\end{array}$ & $\begin{array}{c}11-20 \\
(5)\end{array}$ & $\begin{array}{c}21-30 \\
(6)\end{array}$ & $\begin{array}{c}31-40 \\
(7)\end{array}$ & $\begin{array}{c}41-50 \\
(8)\end{array}$ & $\begin{array}{c}51-60 \\
(9)\end{array}$ \\
\hline 1946 & 300.35 & 0.29 & 0.11 & 0.25 & 0.19 & 0.17 & 0.14 & 0.13 & 0.11 \\
\hline 1947 & 289.28 & 0.49 & 0.16 & 0.31 & 0.19 & 0.15 & 0.13 & 0.12 & 0.11 \\
\hline 1948 & 211.42 & 0.24 & 0.10 & 0.24 & 0.19 & 0.16 & 0.14 & 0.14 & 0.13 \\
\hline 1949 & 189.78 & 0.30 & 0.12 & 0.25 & 0.20 & 0.16 & 0.14 & 0.13 & 0.12 \\
\hline 1950 & 201.63 & 0.53 & 0.15 & 0.31 & 0.17 & 0.15 & 0.14 & 0.12 & 0.11 \\
\hline 1951 & 171.98 & 0.38 & 0.13 & 0.28 & 0.17 & 0.16 & 0.14 & 0.13 & 0.12 \\
\hline 1952 & 210.06 & 0.79 & 0.21 & 0.37 & 0.16 & 0.14 & 0.12 & 0.11 & 0.09 \\
\hline 1953 & 225.92 & 0.77 & 0.23 & 0.39 & 0.17 & 0.13 & 0.11 & 0.10 & 0.10 \\
\hline 1954 & 226.54 & 0.51 & 0.18 & 0.31 & 0.20 & 0.16 & 0.13 & 0.11 & 0.10 \\
\hline 1955 & 265.79 & 0.49 & 0.20 & 0.31 & 0.22 & 0.17 & 0.12 & 0.10 & 0.08 \\
\hline 1956 & 211.02 & 0.52 & 0.21 & 0.33 & 0.22 & 0.16 & 0.11 & 0.10 & 0.09 \\
\hline 1957 & 248.14 & 1.27 & 0.30 & 0.46 & 0.16 & 0.12 & 0.10 & 0.09 & 0.07 \\
\hline 1958 & 231.07 & 0.87 & 0.29 & 0.43 & 0.18 & 0.13 & 0.11 & 0.08 & 0.07 \\
\hline 1959 & 200.01 & 0.57 & 0.21 & 0.34 & 0.20 & 0.15 & 0.13 & 0.10 & 0.08 \\
\hline 1960 & 228.08 & 1.26 & 0.29 & 0.44 & 0.17 & 0.13 & 0.11 & 0.08 & 0.07 \\
\hline 1961 & 217.71 & 0.64 & 0.24 & 0.37 & 0.20 & 0.15 & 0.12 & 0.09 & 0.07 \\
\hline 1962 & 225.82 & 0.88 & 0.27 & 0.41 & 0.19 & 0.15 & 0.11 & 0.08 & 0.06 \\
\hline 1963 & 280.81 & 0.91 & 0.28 & 0.43 & 0.18 & 0.14 & 0.10 & 0.08 & 0.07 \\
\hline 1964 & 219.09 & 0.75 & 0.24 & 0.37 & 0.20 & 0.16 & 0.12 & 0.09 & 0.07 \\
\hline 1965 & 325.09 & 1.26 & 0.34 & 0.51 & 0.15 & 0.11 & 0.09 & 0.08 & 0.06 \\
\hline
\end{tabular}

Source: Variety.

and Bridge on the River Kwai (\$17.2 million); in 1960, Ben Hur (\$38 million); in 1962 West Side Story (\$22 million); in 1963 Cleopatra (\$23.5 million) and How the West Was Won (\$23 million); and in 1965, The Sound of Music (\$42.5 million), Mary Poppins (\$31 million), My Fair Lady (\$30 million), and Goldfinger ( $\$ 22$ million). (The figures in parentheses represent the North American rental income reported in Variety.) However, this upward trend was highly volatile as is evident from the coefficient of variation statistic found in column 2, with marked falls in rental income being experienced in 1954, 1959, 1961, and 1964. ${ }^{46}$

The growth in the market share of the annual top ten films over the period of this investigation was of course at the expense of the shares taken by the other categories. Distinctive downward trends are noticeable in films grouped into ranks lower than 20, with their market share falling by approximately a third in the case of the films ranked 31 to 40 and by half in the bottom two categories. In 1946 the share of the top ten films was a little over

\footnotetext{
${ }^{46}$ Taking the top 60 films only, the autocorrelation of the annual number one films with their oneyear lagged values $(t-1)$ was very much lower $(r=0.11)$ than for similar series featuring the tenth film $(r=0.56)$ and median film $(r=0.60)$.
} 
twice that of those ranked between fifty-first and sixtieth. By the 1960s the difference had increased to multiples of seven and above. ${ }^{47}$ This growing inequality of rental incomes causes annual Gini coefficients to trend upwards over the period. ${ }^{48}$

\section{THE IMPACT ON THE INDUSTRY}

During the two decades prior to the Paramount decree, Hollywood's principal studios had pursued a portfolio approach to risk management through the production of a range of films in which the higher risks associated with big budget production were offset by a greater number of middleand low-budget films for which revenues were less variable and more evenly spread. ${ }^{49}$ The increasing skew of rental income reported in the previous section, manifest in the dramatic decline in the real earnings of sub-top-20 films, made portfolio production less tenable as the 1950s wore on, leading to the increase in independent production which David Bordwell, Janet Staiger, and Kristin Thompson have termed the "package-unit" system.

Rather than an individual company containing the source of the labour and materials, the entire industry became the pool for these... This system of production was intimately tied to the post-war industrial shift: instead of the mass production of many films by a few manufacturing firms, now there was the specialised production of a few films by many independents. The majors acted as financiers and distributors. ${ }^{50}$

The trend in independent production, defined by John Izod as ". . . the work of companies that neither own nor are owned by a distribution company," is shown in Table 5. ${ }^{51}$ From the copyright-ownership records it is clear that for Loew's-MGM, Paramount, Twentieth Century Fox, and Warners the scale and importance of wholly in-house production fell. The main change occurred between 1956 and 1960 with the completion of the divestiture process, and accelerated during the next five-year period as the major studios transformed themselves into distributor-financiers handling annual portfolios of films in which investment risk was shared to an increasing degree with independent producers. ${ }^{52}$ The studio that bucked the trend

\footnotetext{
${ }^{47}$ The Gini coefficient values would of course have been much higher had rental incomes of the full annual population of films released onto the American market been known.

${ }^{48}$ In assessing the value of the Gini coefficient, it must be remembered that it is based on the truncated sample of the annual top 60 films and would be very much nearer to one if computed for the whole population of annual releases.

${ }^{49}$ See Sedgwick and Pokorny, "Risk Environment."

${ }^{50}$ Bordwell, Staiger, and Thompson, Classical Hollywood Cinema, pp. 330-31.

${ }^{51}$ Izod, Hollywood, p. 125.

${ }^{52}$ Information on the copyright ownership of films is found in the Library of Congress Catalog of Copyright Entries: Motion Pictures. I am indebted to Bernard Hrusa-Marlow for bringing this source to my attention.
} 
TABLE 5

THE “MAJOR” STUDIOS' CONTROL OF COPYRIGHT

\begin{tabular}{|c|c|c|c|c|}
\hline $\begin{array}{l}\text { "Major" } \\
\text { Studios }\end{array}$ & $\begin{array}{l}\text { Number of } \\
\text { "Top Grossing" } \\
\text { Films } \\
\text { Distributed } \\
\text { (1) }\end{array}$ & $\begin{array}{l}\text { Number of } \\
\text { "Top Grossing" } \\
\text { Films Credited } \\
\text { to the Studio } \\
\text { (2) }\end{array}$ & $\begin{array}{l}\text { Number of "Top } \\
\text { Grossing" Films } \\
\text { Where Copyright } \\
\text { Owned by Studio } \\
\text { (3) }\end{array}$ & $\begin{array}{c}\text { Ratio of } \\
\text { Column } 3 \text { to } \\
\text { Column } 1 \\
\text { (4) }\end{array}$ \\
\hline \multicolumn{5}{|l|}{ Columbia } \\
\hline $1946-1950$ & 21 & 16 & 14 & 0.67 \\
\hline 1951-1955 & 36 & 24 & 20 & 0.56 \\
\hline 1956-1960 & 45 & 20 & 16 & 0.36 \\
\hline $1961-1965$ & 52 & 8 & 7 & 0.13 \\
\hline \multicolumn{5}{|l|}{ Disney-BV } \\
\hline 1954-1955 & 6 & 6 & 6 & 1.00 \\
\hline $1956-1960$ & 15 & 14 & 14 & $0.93^{\mathrm{a}}$ \\
\hline 1961-1965 & 25 & 25 & 25 & 1.00 \\
\hline \multicolumn{5}{|l|}{ Loew's-MGM } \\
\hline 1946-1950 & 87 & 85 & 86 & 0.99 \\
\hline 1951-1955 & 97 & 96 & 96 & 0.99 \\
\hline 1956-1960 & 65 & 38 & 31 & 0.48 \\
\hline $1961-1965$ & 63 & 13 & 18 & 0.29 \\
\hline \multicolumn{5}{|l|}{ Paramount } \\
\hline $1946-1950$ & 63 & 59 & 51 & 0.81 \\
\hline 1951-1955 & 85 & 62 & 67 & 0.79 \\
\hline 1956-1960 & 56 & 20 & 23 & 0.41 \\
\hline $1961-1965$ & 44 & 6 & 6 & 0.14 \\
\hline \multicolumn{5}{|l|}{ RKO } \\
\hline $1946-1950$ & 48 & 22 & 14 & 0.29 \\
\hline $1951-1955$ & 38 & 17 & 20 & 0.53 \\
\hline 1956-1957 & 5 & 3 & 5 & 1.00 \\
\hline \multicolumn{5}{|l|}{ Twentieth } \\
\hline \multicolumn{5}{|l|}{ Century Fox } \\
\hline $1946-1950$ & 74 & 74 & 74 & 1.00 \\
\hline 1951-1955 & 110 & 104 & 104 & 0.95 \\
\hline $1956-1960$ & 75 & 60 & 54 & 0.72 \\
\hline 1961-1965 & 45 & 18 & 19 & 0.42 \\
\hline \multicolumn{5}{|l|}{ Universal } \\
\hline 1946-1950 & 33 & 27 & 24 & 0.73 \\
\hline 1951-1955 & 88 & 88 & 88 & 1.00 \\
\hline $1956-1960$ & 44 & 38 & 40 & 0.91 \\
\hline $1961-1965$ & 44 & 10 & 13 & 0.30 \\
\hline \multicolumn{5}{|l|}{ Warners } \\
\hline 1946-1950 & 64 & 59 & 50 & 0.78 \\
\hline $1951-1955$ & 94 & 71 & 66 & 0.70 \\
\hline $1956-1960$ & 49 & 24 & 27 & 0.55 \\
\hline $1961-1965$ & 25 & 11 & 11 & 0.44 \\
\hline \multicolumn{5}{|l|}{ Total } \\
\hline $1946-1950$ & 396 & 348 & 319 & 0.81 \\
\hline $1951-1955$ & 563 & 476 & 475 & 0.84 \\
\hline $1956-1960$ & 364 & 228 & 221 & 0.61 \\
\hline 1961-1965 & 273 & 66 & 74 & 0.27 \\
\hline
\end{tabular}

${ }^{a}$ The film that caused this proportion to fall below 1.0 was The Big Fisherman (1959). Source: Library of Congress Catalog of Copyright Entries: Motion Pictures. 
was Disney with its distribution arm Buena Vista. However, as is evident from a comparison of columns 1 and 2 in Table 5, while the major studios cut back on production, their share of the top end of the market as distributors remained dominant and continued to be so, as Asu Aksoy and Kevin Robins have shown, for the remainder of the century. ${ }^{53}$ For these authors independent production was dependent on the major studios and should be seen as the consequence of their decision to produce, or co-finance, and distribute fewer but more-costly films, a strategy designed to attract occasional filmgoers back to the theater by offering superior attractions. ${ }^{54}$

\section{PRODUCT DIFFERENTIATION}

In most product and service markets "quality" goods have carried premium prices denoting the willingness of some consumers to pay higher prices for (presumably) perceived differences in utility. It is interesting to note that film exhibition has rarely engaged in this business practice, with admission prices in all but exceptional cases remaining invariant, irrespective of the film being shown. ${ }^{55}$ Consequently, the question arises of how choices were made in the absence of relative price differentials among films shown in a locality. ${ }^{56}$

If novelty is an irreducible characteristic of film as a commodity, it follows that, ex ante, consumers do not know fully what they want. Arthur De Vany and W. David Walls express this point well when arguing that "Film audiences make hits or flops and they do it, not by revealing preferences they already have, but by discovering what they like." ${ }^{57}$ Furthermore, audiences cannot evaluate a particular film fully until they have experienced it. ${ }^{58}$ Implicit in these powerful ideas is the role of the film producer as an image entrepreneur, a person who is engaged in bringing to audiences pleasures that they could not fully imagine. As a rule Hollywood used stars, genres, directors, styles, storyline, story situation and ethos, together with enthralling technologies, in efforts to attract audiences by offering them strong novel pleasures while at the same time attenuating the risk associated with surprise..$^{59}$ The process was an interactive one with the production-distribution side of the industry engaged in three types of activity: responding to

\footnotetext{
${ }^{53}$ Aksoy and Robins, "Hollywood."

${ }^{54}$ Aksoy and Robins, "Hollywood," p. 8. See also, Scott Berg, Goldwyn, p. 470

${ }^{55}$ For an explanation of the pricing practices in the industry see Sedgwick, Popular Filmgoing, pp. 56-61.

${ }^{56}$ Elsewhere, I have proposed a cognitive process in which audiences have prior commitments to quality and seek stimuli that are consonant with them. Sedgwick, Popular Filmgoing; Gilad, Kaish , and Loab, "Cognitive Dissonance."

${ }^{57}$ De Vany and Walls, "Bose-Enstein Dynamics," p. 1493.

${ }^{58}$ Nelson, "Advertising."

${ }^{59}$ Sedgwick and Pokorny, "Risk Environment," pp. 196-98; and Izod, Hollywood, p. 56.
} 
consumer preferences as previously revealed; offering novelty; and finally, attempting to shape audience appetites, needs, and expectations.

From the early years of film's existence as a commodity, audiences have been attracted to particular genres, such as westerns and musicals, as well as to films with high levels of spectacle. During the period of this investigation a number of new generic conventions emerged from the consumption interests of young people, in particular, rock and roll and sex. ${ }^{60}$ Nevertheless, as has been discussed, the progressively more unequal distribution of film revenues suggests that, increasingly, large-scale audiences were only attracted by the promise of extraordinary film experiences. One approach to analyzing these differences in the alignment of audiences is provided by the distinction between vertical and horizontal forms of product differentiation. Michael Waterson provides a useful definition:

If we consider a class of goods as being typified by a set of (desirable) characteristics, then two varieties are vertically differentiated when the first contains more of some or all characteristics than the second, so that all rational consumers given a free choice would opt for the first. They are horizontally differentiated when one contains more of some but fewer of other characteristics, so that two consumers exhibiting different tastes offered a free choice would not unambiguously plump for the same one. ${ }^{61}$

\section{Horizontal Product Differentiation}

Genre, in the words of Izod, enables ". . . the uniqueness of the product to be strikingly de-emphasized," serving to group films that share particular characteristics traits. $^{62}$ In the spirit of Hotelling it is possible to conceive of genres, placed along a continuum, attracting particular audiences. ${ }^{63}$ Richard Maltby has argued that:

Classical Hollywood thus recognised a number of quite clearly differentiated groups of viewers and organised its output to provide a range of products that would appeal to different fractions of the audience. Movies were assembled to contain ingredients appealing to different generically defined areas of the audience, so that their marketing and exploitation could position each picture in relation to one or more of those "taste" publics. ${ }^{64}$

Genre classification, however, is not an exact science. Various agenciesaudiences, the film trade, film critics, academics - have evolved distinctive genre systems for their own particular purposes ${ }^{65}$ Clearly, with such fluidity

\footnotetext{
${ }^{60}$ Docherty, "Teenagers and Teenpics."

${ }^{61}$ Waterson, "Product Differentiation," p. 106. See also Beath and Katsoulacos, Product Differentiation

${ }^{62}$ Izod, Hollywood, p. 56.

${ }^{63}$ Hotelling, "Stability."

${ }^{64}$ Maltby, Hollywood Audiences, p. 4.

${ }^{65}$ See Altman, Film/Genre; and Neale, Genre.
} 
of usage, some form of working categorization of genres will have to serve. The Motion Picture Guide provides a genre classification for each of its entries, and this has been used to provide an initial analysis of the sample of top ranking films listed annually in Variety. The 1,820 films in the sample are differentiated under no less than 170 distinct genre categories, most of which are hybrid. For example, two films are classified as "Adventure History Dramas," three films as "Drama History Epics," and three as "History Drama Adventures." The assumptions made to reduce the categories to a manageable number for analytical purposes are: that the forward slash commonly deployed in the Guide can be ignored as it is not at all clear that it is used consistently by its writers; and that the order of the categorizing terms used reflects the predominance of the first listed term as a descriptor of the film in question. In this way the number of genre categories has been reduced to 23, two of which - Cinerama and documentary - are not included in the Motion Picture Guide. These are listed in Table 6 along with the number of annual "Top Grossing" films and top-ten films grouped under those headings for the period 1946 to 1965 . Column 4 lists the genre categories identified by Maltby and Neale as those most commonly used as descriptors by audiences and personnel working in the film industry. Indeed the correspondence between the most popular genre categories listed in column 2 and the Maltby-Neale categories is very close. Neale's list includes three genres not found in the Motion Picture Guide - the epic, the social-problem film, and the teen pic. ${ }^{66}$ Conversely, the most frequently used genre categories in the Guide that are not found in the Maltby-Neale lists are fantasy, historical, romance, and spy films. The principal genres were action-adventure, comedy, crime, drama, musicals, war, and westerns. These seven genres accounted for $1,530-84$ percent - of the 1,820 topranking films. Three of the genres - crime, war, and westerns - intimate a concern with killing and death, whereas comedy and musical genres suggest gaiety and light heartedness, with drama and action-adventure lying somewhere in between. On this basis it is possible to think of these genres as being located along a continuum with comedy and war at the poles, with each genre being a near-neighbor of at least one but no more than two others. Films from genres that are close to one another along the continuum were more likely to be close substitutes for one another than those from more "distant"genres.

These ideas are developed in Figure 1, which shows that the dominant genres can be organized empirically into four primary clusters of films in which drama is the common element. These clusters are drama/comedy/ musical (944 films), drama/crime/war-western (878 films), drama/action-

$$
\text { p. } 51 \text {. }
$$

${ }^{66}$ Neale adopts the eight genre types identified by Maltby and adds six more. See Neale, Genre, 
TABLE 6

GENRE TYPES AND FREQUENCIES

\begin{tabular}{|c|c|c|c|}
\hline $\begin{array}{c}\text { Motion Picture } \\
\text { Guide Genre } \\
\text { Classification } \\
\text { (1) }\end{array}$ & $\begin{array}{l}\text { Number of Films } \\
\text { in Each Genre } \\
\text { Category } \\
\text { (2) }\end{array}$ & $\begin{array}{c}\text { Number of "Top-10" } \\
\text { Films in Each Genre } \\
\text { Category } \\
\text { (3) }\end{array}$ & $\begin{array}{c}\text { The Maltby (1995)/ } \\
\text { Neale }(2000) \\
\text { Classification } \\
\text { (4) }\end{array}$ \\
\hline Action-Adventure & 127 & 12 & $\checkmark$ \\
\hline Animation & 13 & 4 & \\
\hline Biblical & 9 & 5 & \\
\hline Biography & 25 & 2 & $\checkmark$ \\
\hline Children & 7 & 1 & \\
\hline Comedy & 343 & 49 & $\checkmark$ \\
\hline Crime & 99 & 2 & $\checkmark$ \\
\hline Drama & 408 & 44 & $\checkmark$ \\
\hline Fantasy & 20 & 1 & \\
\hline Historical & 57 & 13 & \\
\hline Horror & 25 & 2 & $\checkmark$ \\
\hline Juvenile & 4 & 0 & \\
\hline Musical & 243 & 33 & $\checkmark$ \\
\hline Mystery & 15 & 0 & \\
\hline Period & 5 & 0 & \\
\hline Romance & 39 & 3 & \\
\hline Sci-fi & 24 & 1 & $\checkmark$ \\
\hline Spy & 23 & 4 & \\
\hline Suspense-Thriller & 10 & 2 & $\checkmark$ \\
\hline War & 93 & 9 & $\checkmark$ \\
\hline Westerns & 217 & 9 & $\checkmark$ \\
\hline Cinerama* & 4 & 4 & \\
\hline Documentary* & 10 & 0 & \\
\hline Epic** & & & $\checkmark$ \\
\hline Social Problem** & & & $\checkmark$ \\
\hline Teen Pic $* *$ & & & $\checkmark$ \\
\hline Total & 1820 & 200 & \\
\hline
\end{tabular}

* Films listed in these two categories are not included in the Motion Picture Guide.

** Genres identified by Neale but not recognized as such by the Motion Picture Guide.

Sources: Variety; Maltby, Hollywood Cinema; and Neale, Genre and Hollywood.

adventure/comedy (878 films), and drama/action-adventure/war-westerns (845 films). The numbers in parentheses are taken from Table 6 and represent the number of "Top Grossing" films identified by the Motion Picture Guide belonging to each genre category. War and western films are placed together on the grounds that they often share common themes and thus might be considered very near neighbors. Under the proposed schema several genres are subsumed. For example, those films that the Motion Picture Guide identified as historical are closely associated with a parent genre found within one of the cluster groupings. Thus War And Peace (1956) is categorised as a "historical drama" and can be located in the drama/actionadventure/ war-western cluster. Biography and romance films can be similarly treated, so that, for example, the biography Viva Zapata (1952) may be thought of as being located in the same cluster as War And Peace whereas 

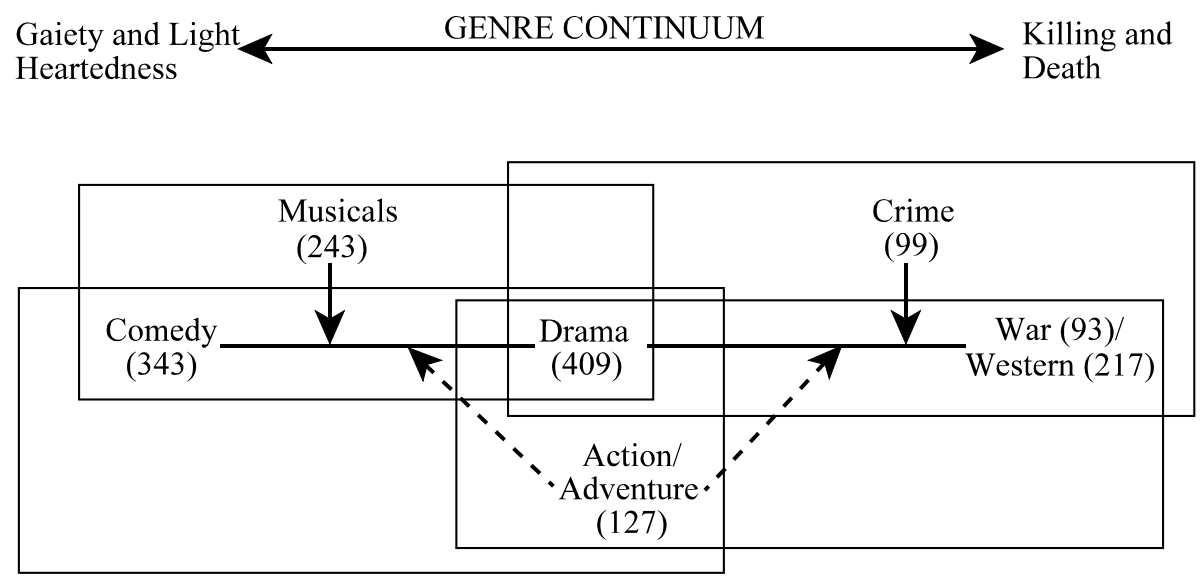

FIGURE 1

THE DISTRIBUTION OF “TOP-GROSSING” FILMS WITHIN GENRE CLUSTERS

Sources: Variety; and Motion Picture Guide.

Roman Holiday (1953) classified as a "romance-comedy" will be positioned on the drama-comedy line of the drama/comedy/musical cluster. Of the other notable generic categories, spy drama is closely associated to crime in the drama/crime/war-western cluster, along with horror and mystery, whereas science fiction is better located in the drama/action-adventure/war-western cluster. The clusters are intuitively conceived, based on the likelihood of near- and distant-neighbor characteristics attracting distinct "taste publics." The four clusters in Figure 1 contain broadly comparable numbers of films, which supports the idea of a range of audience tastes that are spread evenly across genres.

Table 7 provides an annual breakdown of the incidence of the Motion Picture Guide genre categories listed in Table 6. It is clear that whereas films entered under the comedy and drama genres maintain their numbers over the period, this is not true of the other initially very popular genre classifications, although it should be remembered that the number of films listed in Variety is not constant. Nevertheless, these films all grossed at least $\$ 1$ million at the box-office during their initial release or, exceptionally, year of their re-release. The demise of the action-adventure, musical and western during the latter years of the period is particularly noticeable and suggests a movement in taste preferences as new audiences emerged with different outlooks, concerns, and interests.

\section{Vertical Product Differentiation}

The categorization of films under particular genre headings is only part of the story. The exclusive use of genres as the choice criteria would indicate 


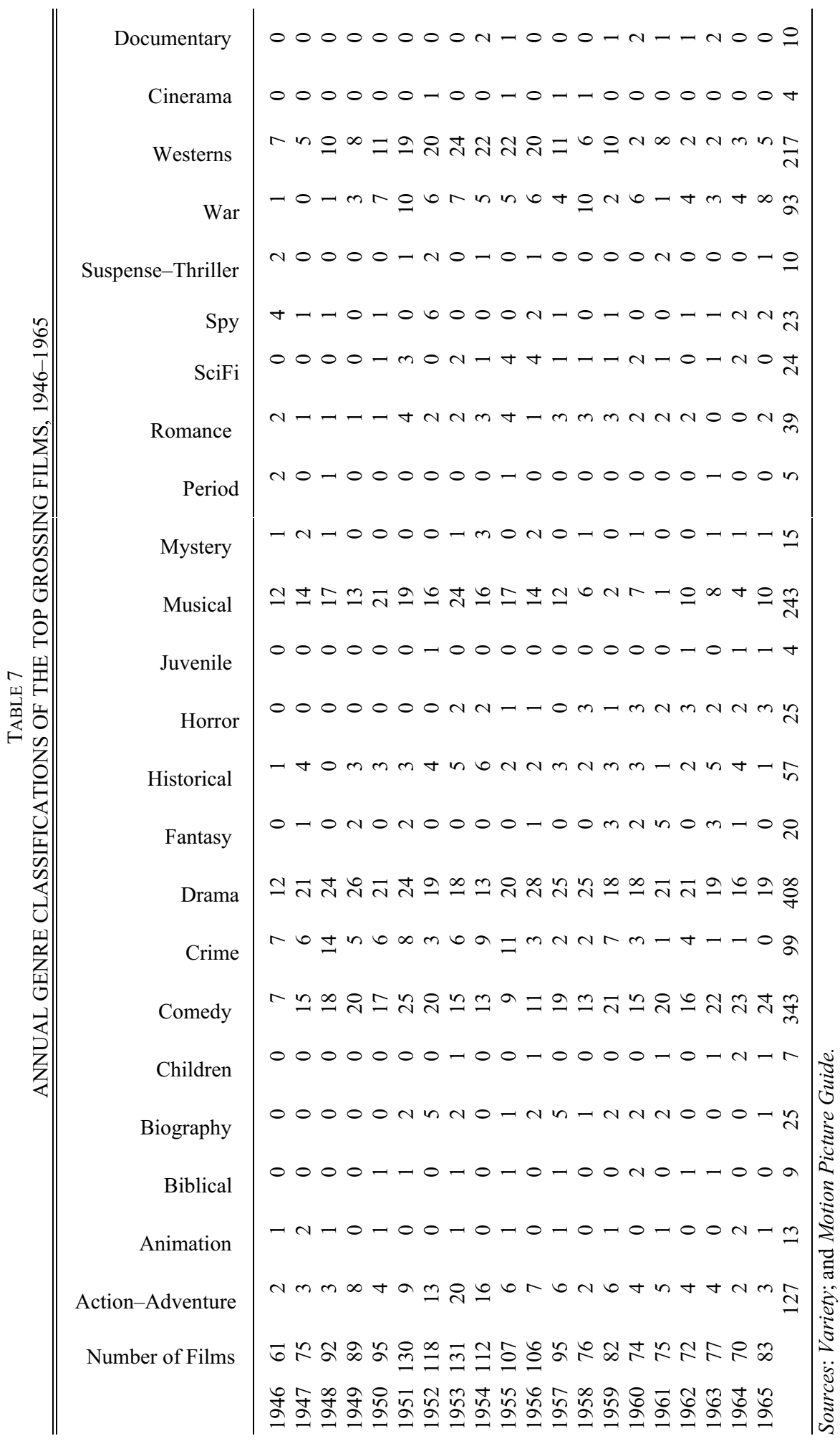


a horizontally differentiated market as described and analyzed by means of Figure 1. However, quality differences exist within genres. For example, in 1952 of the 20 westerns listed as "Top Grossers" High Noon (ninth) was ranked above Bend In The River (fourteenth), which in turn was ranked above Westward The Women (twenty-fifth). If rental income is regarded as a proxy for popularity the implication of these returns is that High Noon promised audiences a higher quality of experience than the other two films. "Quality" in this circumstance refers to standards of pleasure anticipated by audiences. Hence, vertically differentiated markets consist of an array of commodities that can be ranked by criteria that are widely shared, so that, given a common price, a superior commodity would dominate all others in that set. The corollary to this is that in markets where price differentiation prevails, consumers will reveal a willingness to pay for the extra quality offered by top ranking commodities. ${ }^{67}$ As was argued earlier the "system of provision" which has developed around film as a commodity has given emphasis to supply-side adaptability, rather than price flexibility, as the means for responding to variations in demand. ${ }^{68}$ Films such as Gone With the Wind (1939), The Sound of Music (1965), and the more-recent Titanic (1998) can be thought of as supreme examples of vertically differentiated film commodities: films that were considered to be attractions superior in almost all respects to other films on offer at the time by filmgoers at large, many of whom went only rarely to the movies.

Evidence for the co-existence of horizontal and vertical forms of differentiation is found in the skewed distribution of film revenues reported earlier in Table 4. This phenomenon is recognized widely across different periods and markets in film economics-history literature. ${ }^{69}$ The disproportionate share of the market taken by the "hits" of the season indicates that consumers enjoyed a particular quality of pleasure from such films. Moreover, the bunching of such attractions in favor of certain of the genres shown in column 3 of Table 6 suggests that the prospect of value-added pleasures offered by a "hit" transcended particular genre preferences so that the holistic experience promised by a certain Film A was preferred to that offered by Films B . . . Z irrespective of genre: "hit" films promise a superior set of pleasures that attract occasional consumers - those drawn rarely to the cinema by specific attractions - and regular consumers, those whose film-going is more frequent but nevertheless selective. Hence a film such as The Searchers (ranked eleventh in 1956), which generated a rental

\footnotetext{
${ }^{67}$ See Sutton, Sunk Costs; Waterson, "Product Differentiation"; and Beath and Katsoulacos, Product Differentiation.

68 "Systems of provision" as an analytical framework for understanding historically specific relations between consumption and production is developed in Fine and Leopold, Consumption.

${ }^{69}$ See De Vany and Walls, "Bose Einstein Dynamics"; Sedgwick, Popular Filmgoing; and Sedgwick and Pokorny, "Risk Environment."
} 
2.67 times that of the median film for that year, must have attracted audiences other than dedicated "western" filmgoers.

Figure 2 illustrates this argument. Each vertical bar of the three diagrams represents a film from one of the major genres represented in Figure 1. The films are grouped by genre (arranged alphabetically) in descending order of the ratio of each film's rental income to the median film income for the selected years from the Variety sample of "Top Grossing" films. The growing inequality in the annual distribution of rental incomes is evident in that for 1946 the distribution of rental incomes is much flatter than for the other two years whereas that of 1965 is particularly skewed. This implies that film product at the top end of the market became more vertically differentiated over the period, and suggests that audiences were increasingly attracted to the cinema by films that could be marketed as "special events."

The generic composition of the top ten ranking films over the period, set out in Table 6, serves to discriminate between those genres that were regularly associated with popular success and those that were not. The differences are striking when compared in the same table to the distribution of the 1,820 films across the Motion Picture Guide genre classifications. In Figure 1 the four clusters comprise films in numbers that are comparable between any one cluster and another. This is not the case in Figure 3, where 126 of the 200 top 10 grossing films - again not counting the minor genres-form the drama/comedy/musical cluster, compared to 105 films in the drama/ action-adventure/comedy cluster, 74 in the drama/action-adventure/warwesterns cluster and 64 in the drama/action-adventure/crime cluster. Of further interest, when the analysis is confined to the highest-ranking films, is the greatly increased significance of films labeled "historical." Also, although numerically small, a high proportion of films from the animation, biblical, and spy genres achieve top-ten success.

\section{STARS AS MARKERS OF QUALITY}

A crucial element in the metamorphosis of Hollywood away from the command structures of the old studio system to arm's length contracting based on particular projects was the release of stars from long term contracts with the studios. ${ }^{70}$ The growing absolute and relative value and importance of top-ten rental earnings during this period gave greater emphasis to the differentiating role played by stars. ${ }^{71}$

The function of providing information ex ante for audiences is the subject of a recent work on the phenomenon of stardom by Steven Albert who

\footnotetext{
${ }^{70}$ Storper, "Flexible Specialisation"; and Weinstein, "Profit-Sharing Contracts."

${ }^{71}$ Bordwell, Staiger, and Thompson, Classical Hollywood, p. 332
} 

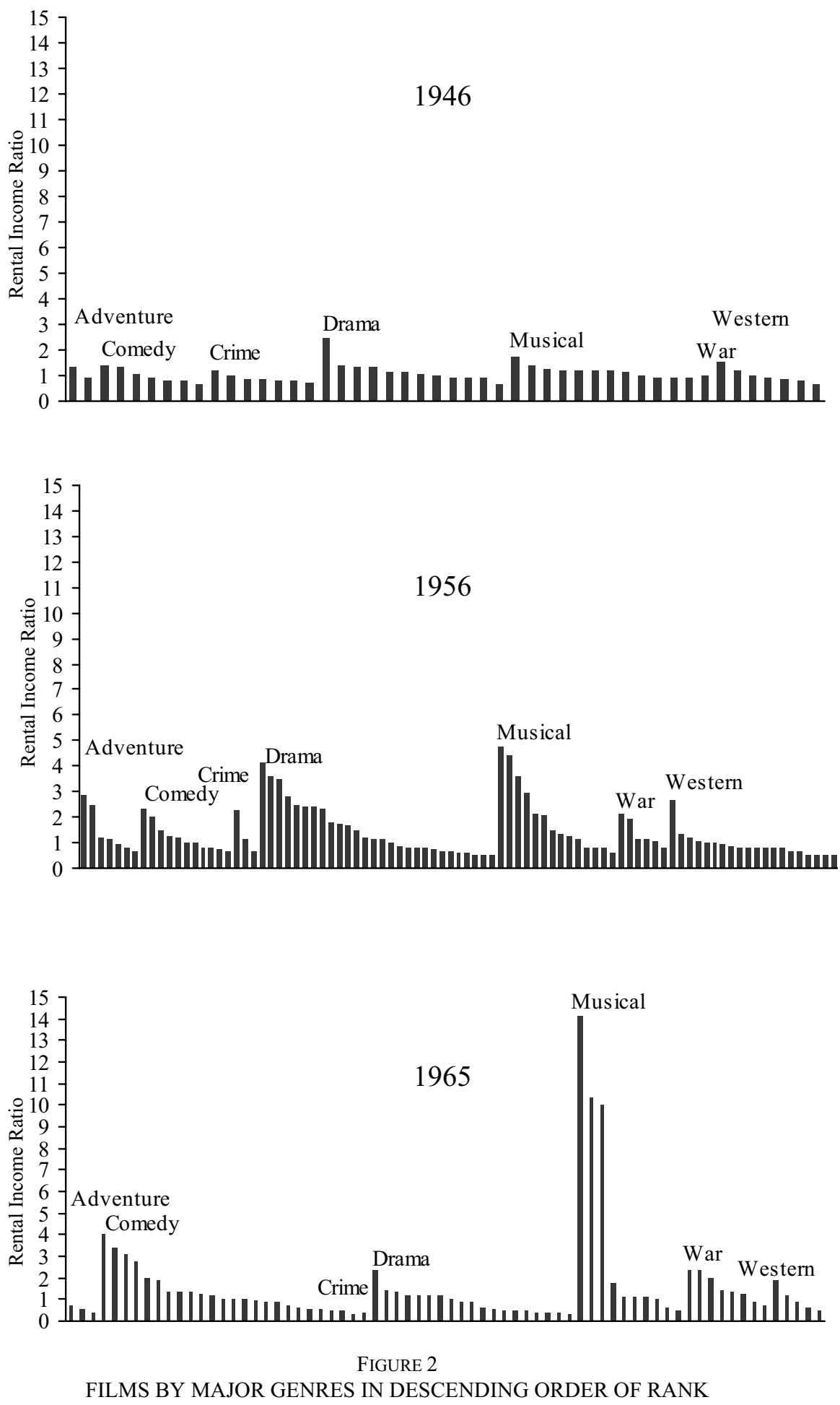

Note: Each film's income / median film's income based on Variety "Top Grossing” sample. 

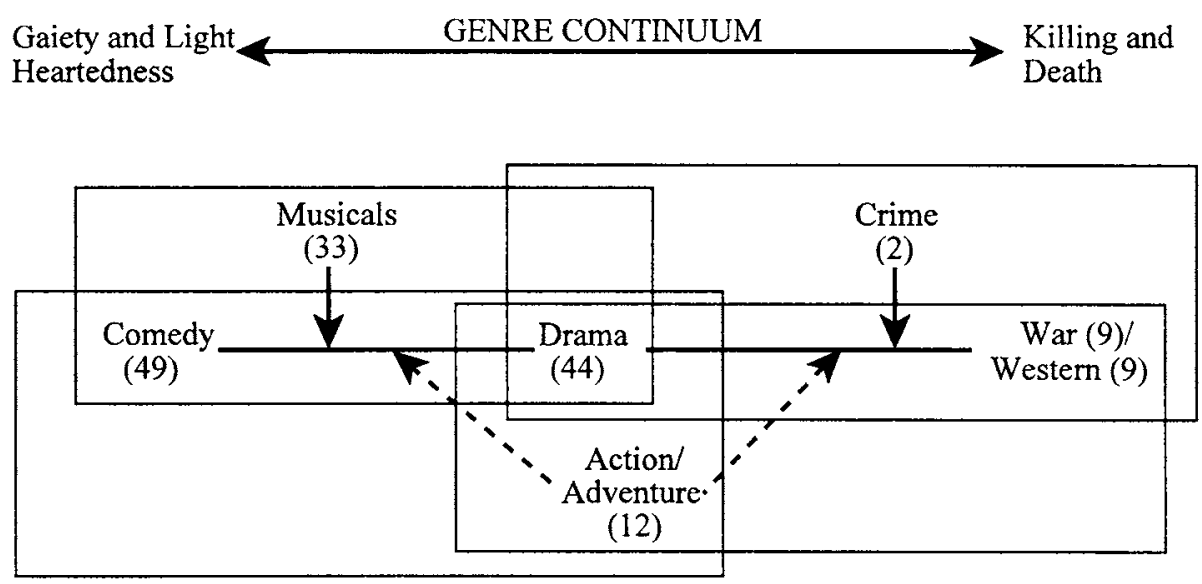

FIGURE 3

THE DISTRIBUTION OF TOP TEN FILMS IN GENRE CLUSTERS

Sources: Variety; and Motion Picture Guide.

argues that the previous successful performances of stars serve as markers for potential audiences, maintaining that “. . . stars are important because they are the least noisy and most consistent marker for successful film types." "2 The stochastic model he adopts predicts that "the likelihood of a film of a particular type succeeding is proportional to all films of a similar type that have produced similar levels of success." 73 The probability of a star appearing in $i$ successful films is $f(i)$ according to the model

$$
f(i)=1 / i(i+1), \quad \sum_{i=1}^{\infty} f(i)=1
$$

The model predicts that half the stars will have only a single success, one sixth will have two successes, one twelfth will have three successes, and so on.

Looking at the principal star in each top-20 film for the period 1960 to 1995, Albert finds that there is good correspondence between predicted and actual results up to seven successes. However, the model is unsatisfactory because it greatly over-predicts the number of stars with high levels of

\footnotetext{
${ }^{72}$ Albert, "Movie Stars," p. 251. In contrast, De Vany and Walls ("Uncertainty") and Ravid ("Information") cast doubt on the rationality of using stars. See Pokorny and Sedgwick, "Stardom" for an account of the debate.

${ }^{73}$ Albert, "Movie Stars," p. 253. Albert draws on the work of Chung and Cox, "Superstardom," which in turn is based on a model first identified by Yule ("Evolution") and later developed by Simon ("Skew Distribution").
} 
success. ${ }^{74}$ An allowance for the limited life and output of stars, made by assuming that they are subject to exponential decay, can remedy this fault so that the model predicts fewer stars with great success. It also improves the correspondence for stars with few successes so that there is sound ground to proceed with the analysis.

A broader enquiry than that undertaken by Albert is reported in Table 8, which reports the two leading stars of each film listed in the annual top-10, top-20 and top-60 films between 1946 to $1965 .{ }^{75}$ It is clear that the great majority of the talent represented in Table 8 are not top ranking stars. In the table, 684 (first- or second-credited) stars are shown to have appeared at least once in a top-60 film, of which over half (366) were not credited with a leading role in a single top-20 production, and just under three quarters (481) did not appear in a top-ten production. Indeed, 332 stars appeared in one top-60 film only. In contrast, the table also shows that a small number of stars had repeated top-ten successes. These are named in Table 9. However, as is evident, their success was not always consistent during the period 1946 to 1965. For example, whereas ten of Elizabeth Taylor's 13 top-60 films during the period were ranked in the top-ten of their respective release years, only five of James Stewart's 31 top-60 films and two of Alan Ladd's 24 top-60 films were similarly ranked. ${ }^{76}$ All three were major stars, but as markers they generated different signal strengths to audiences. Indeed, it is apparent that no single template captures the "hit" profiles of the stars listed in Table 9.

Figure 4 shows that each order of top-ten success corresponds to widely differing top-60 levels of success although a general upward trend can be observed. However, by dividing the stars into high-, medium- and low-volume categories it is possible to propose a taxonomy that distinguishes between high-volume frequent-top-ten stars (e.g. Gregory Peck, John Wayne); medium-volume frequent-top-ten stars (Elizabeth Taylor, Marlon Brando); high-volume, recurring-top-ten stars (James Stewart, Doris Day); mediumvolume, recurring-top-ten stars (Rock Hudson, Tony Curtis); low-volume recurring-top-ten stars ( Ingrid Bergman, Grace Kelly); high-volume

\footnotetext{
${ }^{74}$ The Yule distribution predicts that there should be 35 stars with eight or more successes in Albert's data but there are only 17. It implies there should be 14 stars with over 20 successes and five with over 50 successes. In the sample the most successful star has 19 successes. In reality stars are not immortal and appear in a finite number of films, whereas the distribution is based on a pure birth process (i.e., there is no allowance for death) and this long tail was the most desirable feature in the original applications of Simon.

${ }^{75}$ In identifying the top 20 films of each season as being "successful," Albert treats as equal the appearance of stars in films that earn quite different magnitudes of rental income. See Table 4. For this reason, the annual top 10 films - in keeping with the analysis on genre - might be thought of as a sample better suited to illustrate vertical differences between film characteristics.

${ }^{76}$ Using the top 60 films means that stars appearing in films that lie outside of this rank are not included in the analysis.
} 
TABLE 8

DISTRIBUTION OF STARS BY THE NUMBER OF TOP 10, TOP 20, AND TOP 60 FILMS IN WHICH THEY APPEAR

\begin{tabular}{|c|c|c|c|c|c|c|c|c|}
\hline \multirow[b]{3}{*}{ Films } & \multicolumn{2}{|c|}{ Top 10 Films } & \multicolumn{3}{|c|}{ Top 20 Films } & \multicolumn{3}{|c|}{ Top 60 Films } \\
\hline & \multicolumn{2}{|c|}{ Star Credits } & \multirow[b]{2}{*}{ Films } & \multicolumn{2}{|c|}{ Star Credits } & \multirow[b]{2}{*}{ Films } & \multicolumn{2}{|c|}{ Star Credits } \\
\hline & Actual & Expected & & Actual & Expected & & Actual & Expected \\
\hline 1 & 128 & 102 & 1 & 176 & 159 & 1 & 332 & 342 \\
\hline 2 & 32 & 34 & 2 & 57 & 53 & 2 & 117 & 114 \\
\hline 3 & 13 & 17 & 3 & 24 & 27 & 3 & 52 & 57 \\
\hline 4 & 15 & 10 & 4 & 19 & 16 & 4 & 50 & 34 \\
\hline 5 & 9 & 7 & 5 & 10 & 11 & 5 & 20 & 23 \\
\hline 6 & 2 & 5 & 6 & 9 & 8 & 6 & 25 & 16 \\
\hline 7 & 1 & 4 & 7 & 5 & 6 & 7 & 10 & 12 \\
\hline 8 & 0 & 3 & 8 & 1 & 4 & 8 & 11 & 10 \\
\hline \multirow[t]{7}{*}{$>8$} & 3 & 23 & 9 & 6 & 4 & 9 & 13 & 8 \\
\hline & & & 10 & 3 & 3 & 10 & 5 & 6 \\
\hline & & & $>10$ & 8 & 29 & 11 & 7 & 5 \\
\hline & & & & & & 12 & 6 & 4 \\
\hline & & & & & & 13 & 5 & 4 \\
\hline & & & & & & 14 & 6 & 3 \\
\hline & & & & & & $>14$ & 25 & 46 \\
\hline $\begin{array}{l}\text { Total } \\
\text { Stars }\end{array}$ & 203 & & & 318 & & & 684 & \\
\hline $\begin{array}{l}\text { Total } \\
\text { Berths }\end{array}$ & 386 & & & 780 & & & 2,538 & \\
\hline
\end{tabular}

Note: The expected values are derived from the Yule distribution model. The expected numbers are rounded. The top 10 films for the 20 years (1946 to 1965) sum to 200. If each featured two stars the number of star berths would sum to 400 . Accordingly, the annual list of top 20 and top 60 films would generate 800 and 2,400 star berths respectively. The actual number of berths occupied was 386, 780, and 2,358 for the three lists, with the shortfall explained by the success of a small number of Cinerama, documentary, and animation films.

occasional-top-ten stars (Clark Gable, Alan Ladd); medium-volume occasional-top-ten stars (Humphrey Bogart, Robert Mitchum); and finally lowvolume occasional-top-ten stars (Peter O’Toole, Marilyn Monroe). ${ }^{77}$ The personas of these listed stars served to differentiate films in that they offered audiences a distinctive experience, promising exceptional combinations of qualities that were widely perceived as being superior to those of actors starring in non-top-60 films. Nevertheless, poll evidence tells us that each star also attracted distinctive audiences, or "taste publics." " For example, John Wayne can be considered to have been a superior box-office star to Glenn Ford as a leading man in war-western-action type films in terms of

\footnotetext{
${ }^{77}$ The following benchmarks are used: high-volume, 20 films or more; medium-volume, 10-19 films; low-volume fewer than 10 films. The frequency of top- 10 success is also broken down into three groups: frequent, six films or more; recurring, four to five films; and occasional, two to three films.

${ }^{78}$ See the International Motion Picture Almanac for each of the years in the investigation.
} 
TABLE 9

TOP RANKING STARS, 1946-1965

\begin{tabular}{|c|c|c|c|c|c|c|c|}
\hline Star & $\begin{array}{l}\text { Top } 10 \\
\text { Films }\end{array}$ & $\begin{array}{c}\text { Top } 20 \\
\text { Films }\end{array}$ & $\begin{array}{c}\text { Top } 60 \\
\text { Films }\end{array}$ & Star & $\begin{array}{l}\text { Top } 10 \\
\text { Films }\end{array}$ & $\begin{array}{l}\text { Top } 20 \\
\text { Films }\end{array}$ & $\begin{array}{c}\text { Top } 60 \\
\text { Films }\end{array}$ \\
\hline Taylor, E & 10 & 11 & 13 & Monroe, $\mathrm{M}$ & 3 & 5 & 7 \\
\hline Crosby, B & 9 & 14 & 22 & Russell, J & 3 & 4 & 8 \\
\hline Peck, G & 9 & 14 & 27 & Sellers, P & 3 & 4 & 5 \\
\hline Wayne, J & 7 & 17 & 37 & Simmons, $\mathrm{J}$ & 3 & 5 & 6 \\
\hline Brando, $\mathrm{M}$ & 6 & 9 & 14 & Wilde, Cornel & 3 & 3 & 6 \\
\hline Grant, C & 6 & 14 & 21 & Andrews, J & 2 & 2 & 4 \\
\hline Bergman, I & 5 & 8 & 9 & Astaire, F & 2 & 5 & 12 \\
\hline Curtis, T & 5 & 6 & 17 & Baker, C & 2 & 2 & 5 \\
\hline Day, D & 5 & 9 & 25 & Bennett, Joan & 2 & 2 & 4 \\
\hline Hudson, $\mathrm{R}$ & 5 & 10 & 19 & Bogart, H & 2 & 4 & 15 \\
\hline MacMurray, F & 5 & 6 & 9 & Clift, M & 2 & 4 & 5 \\
\hline McGuire, D & 5 & 5 & 7 & Connery, S & 2 & 3 & 4 \\
\hline Sinatra, F & 5 & 13 & 23 & de Havilland, O & 2 & 2 & 8 \\
\hline Stewart, J & 5 & 12 & 31 & Fonda, $\mathrm{H}$ & 2 & 2 & 7 \\
\hline Turner, L & 5 & 9 & 16 & Fontaine, J & 2 & 3 & 4 \\
\hline Brynner, Y & 4 & 4 & 13 & Gable, C & 2 & 9 & 21 \\
\hline Burton, R & 4 & 6 & 9 & Hepburn, K & 2 & 5 & 10 \\
\hline Douglas, K & 4 & 7 & 21 & Howard, $\mathrm{T}$ & 2 & 2 & 4 \\
\hline Hepburn, A & 4 & 5 & 10 & Hutton, B & 2 & 3 & 6 \\
\hline Hope, B & 4 & 7 & 23 & Jones, S & 2 & 3 & 4 \\
\hline Kelly, Grace & 4 & 4 & 6 & Kaye, D & 2 & 3 & 11 \\
\hline Kerr, D & 4 & 9 & 14 & Kelly, Gene & 2 & 5 & 11 \\
\hline Lancaster, B & 4 & 7 & 31 & Kwan, N & 2 & 2 & 2 \\
\hline Lemmon, J & 4 & 6 & 13 & Ladd, A & 2 & 4 & 24 \\
\hline Lewis, J & 4 & 10 & 27 & Leigh, V & 2 & 2 & 4 \\
\hline Martin, D & 4 & 13 & 27 & Lollobrigida, G & 2 & 2 & 5 \\
\hline Niven, D & 4 & 6 & 11 & Loy, M & 2 & 3 & 5 \\
\hline Tracy, S & 4 & 10 & 16 & Mason, J & 2 & 6 & 10 \\
\hline Webb, C & 4 & 5 & 11 & Mitchum, R & 2 & 4 & 18 \\
\hline Wyman, J & 4 & 7 & 12 & Newman, $\mathrm{P}$ & 2 & 6 & 14 \\
\hline Allyson, J & 3 & 4 & 11 & Novak, K & 2 & 4 & 12 \\
\hline Cooper, G & 3 & 4 & 21 & O'Toole, P & 2 & 4 & 4 \\
\hline Ferrer, J & 3 & 3 & 6 & Parks, L & 2 & 2 & 3 \\
\hline Hayward, S & 3 & 6 & 19 & Reynolds, D & 2 & 4 & 13 \\
\hline Heston, C & 3 & 4 & 9 & Saint, E M & 2 & 3 & 4 \\
\hline Holden, W & 3 & 9 & 20 & Taylor, Robert & 2 & 3 & 13 \\
\hline Keel, H & 3 & 3 & 9 & Johnson, Van & 2 & 5 & 10 \\
\hline MacLaine, S & 3 & 4 & 9 & Williams, E & 2 & 4 & 12 \\
\hline
\end{tabular}

Note: Gary Cooper died in 1961, Marilyn Monroe in 1962, Humphrey Bogart in 1957, Clark Gable in 1960, and Alan Ladd in 1964. The Top 20 column includes all Top 10 films plus those ranked 11 to 20. Likewise with Top 60 films.

the ratio of top-ten to top-60 films, i.e., Wayne was a more potent vertically differentiating marker than Ford. However, the same could not be said of Wayne when compared to Cary Grant, a star of comparable verticaldifferentiating potency. Each occupied quite distinct territories along the characteristics continuum of leading men, which is to say that they were 


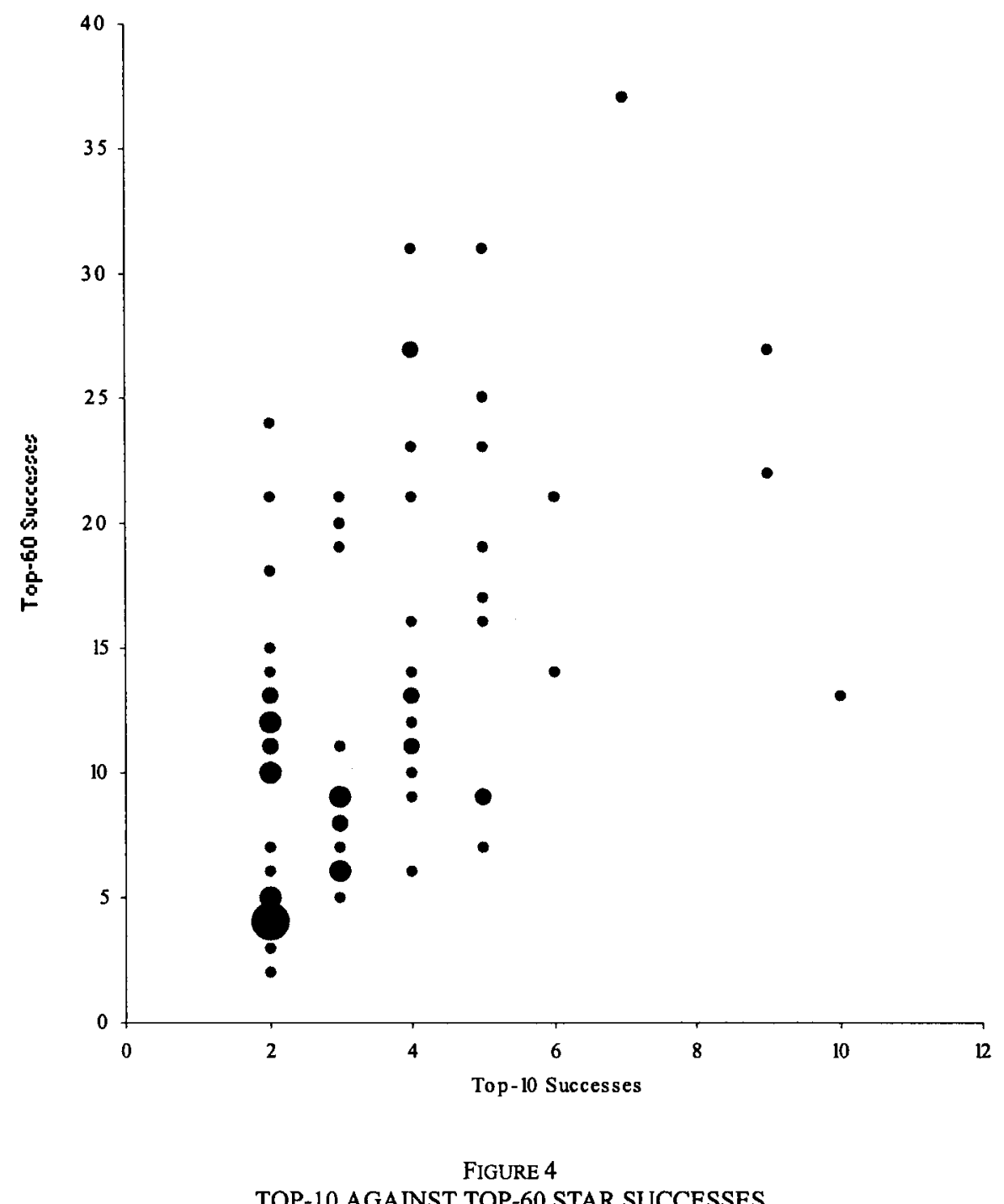

Notes: The diagram represents the data found in Table 9. Multiple occupancy of a position is represented by the size of the marker.

horizontally differentiating markers of quality. Accordingly, although leading stars differentiated films strongly, they did not do so monofactorially. Rather, it was their conjunction with other idiosyncratic and intangible inputs, such as director, screenplay, and genre, which led to the success or otherwise of the films in which they starred. In other words, charisma needs good guidance, good story material and co-stars to work with, and an appropriate setting if it is to be fully effective. 


\section{CONCLUSION}

Hollywood underwent dramatic change during the two decades following the Second World War as the supply side of the industry reacted to rapidly declining audiences. It can be argued in hindsight that the divestiture of movie theaters, forced on Loew's-MGM, RKO, Paramount, Twentieth Century Fox, and Warner Bros. through the Paramount decree of 1948, would have taken place anyway as audiences turned away from the cinema as a regular form of recreation. Evidence of the changing pattern of demand during the period emerges from the study of top-ranking-film rental returns published annually by the trade journal Variety. The market was differentiated both horizontally and vertically, with stars and, to a lesser extent, genre serving as markers. Audiences became increasingly attracted to particular films, rather than films in general. Such films, in providing extraordinary levels of utility, transcended traditional patterns of genre loyalty and achieved very high levels of market penetration. On the supply side, the growing inequality of the rank distribution of film rentals led to: the growth in independent production; the growth in the size of major studio film budgets dedicated to "hit" production; and the transformation of these same studios into distributor-financier-producers. Abandoning in-house portfolio production, Hollywood's major studios adopted a new strategy to reduce their exposure to risk while maintaining their dominance of markets. Bordwell, Staiger, and Thompson refer to this as the package-unit mode of production in which the studios as distributors organized production through contractual relations rather than through in-house co-ordination. By changing in this way Hollywood was able to retain its dominant collective position in the film business.

\section{REFERENCES}

Aksoy, Asu, and Kevin Robins. "Hollywood for the 21st Century: Global Competition for Critical Mass in Image Markets.” Cambridge Journal of Economics 16, no. 1 (1992): $1-22$

Albert, Steven. "Movie Stars and the Distribution of Financially Successful Films in the Motion Picture Industry.” Journal of Cultural Economics 22, no. 4 (1998): 249-70.

Altman, Rick. Film/Genre. London: BFI, 1999.

Balio, Tino. Grand Design: Hollywood as a Modern Business Enterprise. Berkeley: University of California Press, 1993.

Beath, John, and Yannis. Katsoulacos. The Economic Theory of Product Differentiation, Cambridge: Cambridge University Press, 1991.

Belton, John. Widescreen Cinema. Cambridge, MA: Harvard University Press, 1992.

Besas, Peter. Inside Variety: The Story of the Bible of Show Business, 1905-87. New York: Ars Millenii, 2000.

Clawson, Marian, and Jack L. Knetch. The Economics of Outdoor Recreation, Baltimore: John Hopkins University Press, 1966. 
Chung, Kee H., and Raymond A. K. Cox. "A Stochastic Model of Superstardom: An Application of the Yule Distribution." The Review of Economics and Statistics 76 (1994): 771-75.

Conant, Michael. Antitrust in the Motion Picture Industry. Berkeley: University of California Press, 1960.

Crafton, Donald. The Talkies: American Cinema's Transition to Sound, 1926-1931. Berkeley: University of California Press, 1997.

Custen, George F. Twentieth Century's Fox and the Culture of Hollywood. Basic Books, New York, 1997.

De Vany, Albert, and R. Eckert. "Motion Picture Antitrust: the Paramount Cases Revisited." Research in Law and Economics 14, no. 1 (1991): 51-112.

De Vany, Albert, and W. David Walls. "Bose-Einstein Dynamics and Adaptive Contracting in the Motion Picture Industry." Economic Journal 106, no. 439 (1996): 1493-514.

. "Uncertainty and the Movie Industry: Does Star Power Reduce the Terror of the Box Office?” Journal of Cultural Economics 23, no. 4 (1999): 285-318.

Docherty, Thomas. "Teenagers and Teenpics, 1955-1957: A Study in Exploitation Filmmaking.” In The Studio System, edited by J. Staiger, 298-316. New Brunswick, NJ: Rutgers University Press, 1995.

Engerman, Stanley L., and Robert Gallman. The Cambridge Economic History of the United States, Volume III: the Twentieth Century. Cambridge: Cambridge University Press, 2000.

Film Daily: Yearbooks, 1947-1966.

Fine, Ben, and Ellen Leopold. The World of Consumption. London: Routledge, 1993.

Finler, Joel. The Hollywood Story. New York: Crown, 1988.

Friedson, Eliot. "Consumption of the Mass Media by Polish-American Children." Quarterly Review of Film, Radio and Television 9 (1954/55): 92-101.

Gilad, Benjamin, Stanley Kaish, and Peter D. Loab. "Cognitive Dissonance and Utility Maximization: a General Framework.” Journal of Economic Behaviour and Organization 8, no. 1 (1987): 61-73.

Glancy, H. Mark. "MGM Film Grosses, 1924-1948: the Eddie Mannix Ledger." Historical Journal of Film, Radio and Television 12, no. 2 (1992): 127-44.

. "Warner Bros. Film Grosses, 1921-1951: The William Schaefer Ledger." Historical Journal of Film, Radio and Television 15, no. 1 (1995): 55-74;

Gomery, Douglas. Shared Pleasures: a History of Movie Presentation in the United States. London: BFI, 1992.

."Towards a New Media Economics." In Post-Theory: Reconstructing Film Studies, edited by D. Bordwell and N. Caroll, 407-18. Madison: University of Wisconsin Press, 1996.

Greenwald, William. The Motion Picture Industry: An Economic Study of the History and Practices of a Business. Ph.D.thesis, New York University, 1950.

Halliwell's Film Guide, 5th ed. London: Guild, 1986.

Handel, Leo. Hollywood Looks at its Audience. Urbana: University of Illinois Press, 1950.

Halberstam, David. The Fifties. New York: Ballantine Books, 1994

Hotelling, Harold. "Stability in Competition.” Economic Journal 39 (1929): 41-47.

International Motion Picture Almanac

Izod, John. Hollywood and the Box-Office. London: Macmillan, 1988.

Jarvie, Ian. Hollywood's Overseas Campaign: The North Atlantic Movie Trade, 19201950. Cambridge: Cambridge University Press, 1992.

Jewell, Richard B. "RKO Film Grosses, 1929-1951: The C.J. Trevlin Ledger.” Historical 
Journal of Film, Radio and Television 14, no. 1 (1994): 37-51.

Lazarsfeld, Paul F. "Audience Research in the Movie Field." Annals of the American Academy of Political and Social Science 254 (1947): 160-68.

Library of Congress Catalog of Copyright Entries, Motion Pictures, vols. 1940-1949, 1950-1959, 1960-1969.

Maltby, Richard. Hollywood Cinema. Oxford: Blackwell, 1995.

. "Sticks, Hicks and Flaps: Classical Hollywood's Generic Conception of its Audiences." In Identifying Hollywood's Audiences: Cultural Identity and the Movies, edited by M. Stokes and R. Maltby, 23-41. London: BFI, 1999.

Motion Picture Guide.

Neale, Steve. Genre and Hollywood. London: BFI, 2000.

Nelson, Richard. “Advertising as Information.” Journal of Political Economy 81 (1974): $729-45$

Oakley, J. Ronald. God's Country: America in the Fifties, New York: Dember, 1986.

Pokorny, Michael, and John Sedgwick. "Stardom and the Profitability of Filmmaking: Warner Bros. in the 1930s." Journal of Cultural Economics 25, no. 3 (2001): 157-84.

Ravid, S. Abraham. "Information, Blockbusters and Stars: A Study of the Film Industry." Journal Of Business 72, no. 4 (1999): 463-92.

Riesman, David, and Evelyn T. Riesman. "Movies and Audiences." American Quarterly 4 (1952): 195-202.

Rome, Adam. The Bulldozer in the Countryside: Suburban Sprawl and the Rise of American Environmentalism. Cambridge: Cambridge University Press, 2001.

Scott Berg, A. Scott. Goldwyn. London: Hamish Hamilton, 1989.

Sedgwick, John. Filmgoing in 1930s Britain: a Choice of Pleasures. Exeter: Exeter University Press, 2000.

Sedgwick, John, and Michael. Pokorny. "The Risk Environment of Film-Making: Warners in the Inter-War Period." Explorations in Economic History 35, no. 2 (1998): 196-220.

Seldes, Gilbert. The Great Audience. New York: Viking, 1950.

Simon, Herbert A. "On a Class of Skew Distribution Functions." Biometrika 42 (1955): $425-40$

Sklar, Robert. Movie-Made America: A Cultural History of American Movies. New York: Random House, 1975.

."Lost Audience: 1950s Spectatorship and Historical Reception Studies." In Identifying Hollywood's Audiences: Cultural Identity and the Movies, edited by M.Stokes and R. Maltby, 81-92. London: BFI, 1999.

Storper, Michael. "The Transition to Flexible Specialisation in the U.S. Film Industry: External Economies, the Division of Labour, and the Crossing of Industrial Divides." In Post-Fordism: A Reader, edited by A. Amin, 195-226. Oxford: Oxford University Press, 1994.

Sutton, John. Sunk Costs and Market Structure. Cambridge, MA: MIT Press, 1991.

Thompson, Kristin. Exporting Entertainment: America in the World Film Market, 19071934, London: BFI, 1985.

U.S. Department of Commerce, Bureau of the Census, Historical Statistics of the United States: Colonial Times to 1970. Washington, DC: GPO, 1975.

Variety: 1946-1965

Vogel, Harold L. Entertainment Industry Economics. 5th ed. Cambridge: Cambridge University Press, 2001.

Waterson, Michael. "Models of Product Differentiation." In Current Issues in Industrial Economics, edited by J. Cable, 105-33. Basingstoke: Macmillan, 1994. 
Weinstein, Mark, "Profit-Sharing Contracts in Hollywood: Evolution and Analysis." Journal of Legal Studies 27, no. 1 (1998): 67-112.

Yule, G. V. "A Mathematical Theory of Evolution Based on the Conclusions of Dr. J. C. Willis, F.R.S.” Philosophical Transactions of the Royal Society B. 213 (1924): 21-87. 